\title{
The EAERE Celebrates Its 30th Anniversary
}

\author{
Aart de Zeeuw ${ }^{1,2}$ \\ Accepted: 7 April 2020 / Published online: 16 April 2020 \\ (c) Springer Nature B.V. 2020
}

\begin{abstract}
The European Association of Environmental and Resource Economists started around 1990 and celebrates its 30th anniversary this year. The rise of environmental concerns and the wish for more cooperation between scientists within Europe, plus the drive of a few highly motivated people, led to the foundation of this academic institution. This article aims at clarifying the initial steps and the development of this highly successful association. The relationship between economics and the environment is core for the future of our world, and the EAERE was crucial in developing this field. The EAERE has been a stimulus and a home for many scientists who were interested to work in this field and who would otherwise have been quite isolated. The future of the EAERE is bright if it manages to bridge new developments in economics and in the natural sciences, and between academics and policy.
\end{abstract}

Keywords EAERE $\cdot$ Environmental economics $\cdot$ Resource economics

\section{The Years Before}

The European Association of Environmental and Resource Economists did not drop from the blue sky in 1990. The field environmental and resource economics started to take off. That is to say, resource economics was already an old respectable field, with a revival in the early seventies, but now the societal concern for environmental problems was increasing. In the USA, the Association of Environmental and Resource Economists was founded earlier in 1979, and their flagship Journal of Environmental Economics and Management existed since 1974. The European scientists could have simply joined this association, but this was also the time of an increased interest in European academic cooperation. Up to that time, European scientists had contacts within their own country and with colleagues in the USA, but the contacts with colleagues in other European countries were not very

I am grateful to Christian Gollier and Ian Bateman for inviting me to write this article, and to an anonymous referee and Anastasios Xepapadeas for their comments.

Aart de Zeeuw

A.J.deZeeuw@uvt.nl

1 Department of Economics, Tilburg University, P.O. Box 90153, 5000 LE Tilburg, the Netherlands

2 Beijer Institute of Ecological Economics, Royal Swedish Academy of Sciences, Stockholm, Sweden 
strong. Language was an issue, but also the lack of institutions. When the EAERE was officially announced during the First Annual Conference at the University of Venice in April 1990 , it was both a response to the need for developing environmental and resource economics and the need for stronger European cooperation.

\subsection{Environmental Concern}

From the perspective of economics, two lines of history were important. First, economic science had developed a focus on markets and growth, with physical and human capital, but largely ignored the interaction with the natural environment. There have been exceptions, of course, and especially resource economics moved forward in the seventies (Dasgupta and Heal 1979). Second, societal concern in the first decennia after the Second World War focused on restructuring the economies and alleviating poverty, but it was interesting to see that many people already felt that an important issue was missing. For example, Jan Tinbergen, who received together with Ragnar Frisch the first Prize in Economics in honor of Alfred Nobel in 1969, made essential contributions to economic science, as well as to restructuring the Dutch economy and to establishing aid for the developing countries. However, in the course of his career, he switched his focus to the natural environment (Tinbergen 1987). To take another example, Sicco Mansholt, who was a European Commissioner from 1958 until 1972, founded the successful Common Agricultural Policy. However, after his career, he apologized that he forgot to think about the consequences for the natural environment (see Wikipedia).

\subsection{Political Developments}

In the late sixties and early seventies of last century, the political arena also changed. Movements of citizens started to challenge the traditional political parties on a number of issues, such as the Vietnam War, nuclear weapons and nuclear energy, but also environmental issues in general. The movements very often resulted in green parties in Europe that criticized unlimited growth without environmental concern. They added the dimension of sustainability to the traditional dimensions of capital versus labor, and liberals versus socialists. These movements and new political parties were part of the new challenges to economics.

\subsection{The Club of Rome}

In that time, the main challenge to economics was put forward by the Club of Rome ("The Limits to Growth", Meadows et al. 1972). Although they formulated a broad environmental concern, the discussion focused on the limited availability of resources. Many economists were less concerned, because they relied on the mechanisms of scarcity, price, lower use and alternatives. That view got support from the outcome of the famous bet between the biologist Paul Ehrlich and the economist Julian Simon (Sabin 2013). Ehrlich could pick 5 resources and a period of time and Simon betted that the inflation-adjusted prices would not have increased, indicating that these resources had not become scarce. Simon won the bet. Of course, this is not capturing the real problem, but it slowed down the response of economics to the challenge. The real question is whether the scale of all the economic activities is compatible with the carrying capacity of the Earth. Furthermore, economics 
has to take account of the feedbacks of environmental deterioration on, for example, productivity and health, and the direct effects on welfare and life-support systems. Over the last 30 years, the EAERE provides a home for economists who want to work on these issues. However, mainstream economics still ignores the interaction with the natural environment. The same Paul Ehrlich was a plenary speaker at the 15th EAERE Annual Conference in Thessaloniki, Greece, in June 2007. He observed that a long list of typical environmental words had not appeared in any title of the top 146 articles (500 cites or more) in 41 of the most prominent refereed economics journals. There is still a long way to go.

\subsection{A Controversy}

The response of economics to these new challenges is slow. Some people, such as the World Bank economist Herman Daly, were very disappointed and they started with ecological economics. In 1989, the International Society for Ecological Economics and their journal Ecological Economics were founded. Ecological economics breaks with mainstream economics and has strong ties with other disciplines and with societal organizations. I remember that a $\mathrm{PhD}$ student in political science once asked me if she should take a course in environmental economics or in ecological economics. I asked her what she thought the difference was and she answered: "environmental economics is neo-classical economics with an environmental twist and ecological economics is rooted in passion for the environment". At the time, this was a widespread view but it is a caricature, of course, and it does not apply anymore. It is true that environmental economics builds on the strengths of the economics profession, but the passion is there as well. Moreover, economics is reaching out now to the other social sciences, and environmental economics also to the natural sciences. On the other hand, ecological economics has opened up to the new developments in economics. The two groups have the same mission, but environmental economics remains a branch of economics in order not to lose the insights and the tools that economics can provide. Karl-Göran Mäler, an environmental economist, and Buzz Holling, an ecologist, took an interesting initiative. They started to organize meetings with top economists and top ecologists in order to bridge the gap between economics and ecology. These meetings, organized by the Beijer Institute in Stockholm, had a profound effect on the research agenda of many of the participants.

\section{The Early Years}

The EAERE takes the First Annual Conference at the University of Venice in April 1990 as the starting point, but the process to establish the EAERE started before. Early September 1987, Henk Folmer organized the conference "Environmental Policy in a Market Economy" at Wageningen University. At a dinner, he asked around if it could be useful to have something like the EAERE (Folmer 2020). The answers were very positive, and Henk Folmer was asked to take the lead. He got immediate support from well-known European environmental economists at that time, Karl-Göran Mäler, David Pearce and Horst Siebert. He started to prepare the First Annual Conference. Frank Convery put him into contact with Jos Delbeke at the Directorate-General for Environment of the European Commission who was willing to support the EAERE conference. The Fondazione Eni Enrico Mattei (FEEM) and the University of Venice offered to host this conference in Venice. In that time, the conference had a theme. It was called "International Conference on 
Environmental Cooperation and Policy in the Single European Market”. This reflected the interest in policy and in specific European issues. Ignazio Musu was in charge of the local organization. The conference was a huge success and set the tone for all the annual conferences that followed: the combination of serious research and pleasant social and cultural events has been an important strength of the EAERE conferences. From the start, prominent environmental economists from North America participated in the meetings, because it was stimulating and nice but also because at the time North America did not have a similar general annual conference.

\subsection{Establishing a Formal Institution}

In the next steps, the EAERE needed elections for the president and for the council, and needed to find a legal seat in one of the European countries. In the informal stage, Henk Folmer was acting as president, Domenico Siniscalco was acting as secretary-general, and the council consisted of Karl-Göran Mäler, Juan Martinez-Alier, Ignazio Musu, David Pearce and Rüdiger Pethig (EAERE Newsletter, Spring 1991). This group also acted as founding members and designed the Statutes of the EAERE. The FEEM Milano hosted the secretariat. During the Second Annual Conference at the Stockholm School of Economics in June 1991, a nominating committee was installed and elections were organized. Henk Folmer became the first official EAERE president, and Karl-Göran Mäler, Rüdiger Pethig, Ignazio Musu and Tomasz Zylicz were elected as the first council members (David Pearce was elected but could not accept). Marji Lines was appointed as secretarygeneral (EAERE Newsletter, Fall 1991). Rüdiger Pethig established the legal seat of the EAERE in 1992 at the court in Siegen, Germany. A complication was that each newly elected president and council member had to go to the German embassy or consulate in his or her own country for registration. This became easier when the legal seat moved in 2006 to Venice, Italy. The move of the legal seat has probably been the most difficult step in the whole process (Pethig 2020)!

\subsection{The Schools}

It is interesting to note that what characterizes the EAERE today was already present in the early years. Besides the annual conferences, the EAERE also organized, for graduate and post-graduate students, the Autumn Workshop in Environmental Economics (AWEE). The first one took place in 1991, again in Venice and with Ignazio Musu in charge. The venue was the Istituto Veneto di Scienze, Lettere et Arti. The subject was "Managing the International Commons". The lecturers were Scott Barrett, Klaus Hasselmann, Michael Hoel, Karl-Göran Mäler, and myself. It was a great idea to have the climatologist Klaus Hasselmann as one of the lecturers. This idea pops up again in the discussions on the future of the current EAERE Summer School. We had a beautiful lecture room in an old Venetian building at a square, and I had a bedroom in the same building, just under the roof. I remember how I struggled with big old rusty keys to get into the building at night, and how I made my way up in the complete dark because I could not find a light switch. The EAERE was an adventure. A second AWEE was organized in 1992, at the same venue and with the same organizers. The EAERE Council put out a call for organizing the AWEE, for 1 or 2 years, at other European institutes or universities (EAERE Newsletter, Spring 1992). It is not clear whether proposals have been submitted, but the AWEE was not organized again. When I was president of the EAERE in 1998/1999, I felt that this was a big loss, 
and I called Ignazio Musu to ask for his advice. He had become dean of the Venice International University at the beautiful island of San Servolo in Venice. He was willing to lend their facilities to the EAERE for a longer period of time. The FEEM was again willing to support the event, and when my successor Alistair Ulph managed to get support from the European Commission, the school revived in 2000 but now as the Summer School, with Carlo Carraro as the first coordinator. The School is very important for building the next generation of environmental economists. The $\mathrm{PhD}$ students are usually quite isolated in their own university, but in the Summer School they can learn about new developments, they can get feedback on their research, and they can start to build the networks of the future. As of 2018, Lucas Bretschger added the EAERE-ETH European Winter School in Ascona, Switzerland, to the list of EAERE activities.

\subsection{The Journal}

In 1991, Kluwer Academic Publishers started the journal Environmental and Resource Economics (ERE) and they appointed Hans Opschoor as editor and Huib Jansen as assistant editor. The editors write in their first editorial that they want ERE to be oriented to application and relevant to policy makers. Advanced theory will be published, if there is an outlook to application, but no l'art pour l'art (Opschoor and Jansen 1991). The first issue of ERE contains a selection of papers from the First Annual Conference of EAERE. The editors write: "Consequently, this first issue reflects the scientific contents of that conference which was generally more of a theoretical than an empirical nature. This imbalance will be redressed in the following issues of ERE". Nevertheless, ERE and EAERE decide to move ahead together. The name of the journal and the right to appoint the editor remained with Kluwer, but the president of the EAERE was a member of the managing editorial board and twice a year, the EAERE could publish a Newsletter in ERE (the last EAERE Newsletter in ERE appeared in the Spring 1995). In 1996, the editors, the EAERE president and the Kluwer representative wrote in their editorial: "Although the borderline between application-oriented and purely theoretical articles is difficult to draw precisely, the copy flow tends to be, in our view, too much on the theoretical side, not sufficiently applicationoriented" (Opschoor et al. 1996). This controversy has disappeared now. ERE has become a very good established general field journal, and environmental and resource economics just follows the trend in economics: after a strong focus on theory in the eighties and early nineties of last century, the focus has shifted in current times to empirical and experimental research. Science is driven by societal demand, but also by curiosity and by where and how researchers expect to gain new insights.

\subsection{Workshops}

A number of environmental economists in Europe took initiatives to organize workshops, besides the activities of the EAERE, in order to strengthen the development of the field in Europe. In 1990, Rüdiger Pethig organized a symposium on "Conflicts and cooperation in managing environmental resources" in Freudenberg, Germany, where many researchers met for the first time. In 1992, the European Commission launched the Human Capital and Mobility programme, with the purpose to stimulate cooperation between scientists in Europe. Anastasios Xepapadeas was the first to receive a grant to establish a network for investigating the design of economic policy for management of natural resources and the environment (European Commission 1992). The main obligation was to organize 
workshops where the researchers would meet. The European Commission created more funds to support projects and meetings of researchers from different member states. I remember that Carlo Carraro, Anastasios Xepapadeas and I received such a grant, and we organized a few workshops. The same applies to grants for three projects led by Michael Hoel, Henry Tulkens and Alistair Ulph. ${ }^{1}$ Besides establishing the EAERE, financial support by the European Commission for these activities has been very important for developing environmental and resource economics and for building strong European cooperation.

\subsection{The Topics}

The development of environmental and resource economics in Europe was a bit different from the development in the USA. The titles of the First Annual Conference, the first School, and the first workshops showed a focus on policy and international aspects. Other topics were specific issues in developing and Eastern European countries, besides the standard topics energy, pollution, water, resources, trade and accounting. In the USA, the focus was on valuation and cost-benefit analysis. However, since many researchers from the USA participated in the EAERE annual conferences, the programmes contained a number of sessions on valuation, mainly contingent-valuation studies. Initially, Europe focused more on theory, policy and international aspects, and the USA focused more on valuation and cost-befit analysis, but since the EAERE Annual Conference was the main international general conference in environmental and resource economics, it provided both. In 2011, the AERE started an annual summer conference in North America. Contingent valuation is not the main topic anymore, but attention has shifted to general empirical and experimental studies. The same happened in Europe. The development of theory continues but does not have the main attention anymore.

\section{The Later Years}

After the first 5 successful years, the EAERE was still vulnerable. At the start of the $5^{\text {th }}$ EAERE Annual Conference in Dublin, Ireland, it was not clear who would host the next annual conference. During the conference, representatives from Umeå University, Sweden, offered to take up the job. There had been a joint plan by the EAERE, the AERE and the FEEM to organize a World Congress in Italy in 1993, but this had not materialized (EAERE Newsletter, Spring 1992). As I wrote earlier, the Schools did not continue after 1992. However, the EAERE picked up speed again. Offers to host the annual conference in 1996 and 1997 at the Universidade Nova de Lisboa, Portugal, and at Tilburg University, the Netherlands, arrived. Due to a new big effort by the FEEM (notably Carlo Carraro, Domenico Siniscalco and Alessandro Lanza) the First World Congress of Environmental and Resource Economists took place in Venice, in 1998. As I wrote earlier, the Schools made a new start in 2000, also in Venice. The procedures were still a bit informal. I remember that when I was president of the EAERE in 1998/1999, I just called Michael Hoel, Anastasios Xepapadeas and Alistair Ulph to ask if they were willing to organize the annual conferences in 1999, 2000 and 2001 (in Oslo, Crete and Southampton). They said yes, and

${ }^{1}$ Personal communication with Alistair Ulph. 
everything went smoothly, but it was clear that things had to change and the EAERE had to become a professional organization.

\subsection{Secretariat}

As I wrote earlier, the FEEM Milano hosted the EAERE secretariat in the early years, until 1998. After that, the secretariat moved to the affiliation of the president in office. This implied that the secretaries could not pay full attention. Also in the transitions from one place to the other, things got lost. Continuity was needed. When Frank Convery was president of the EAERE in 2004/2005, a permanent secretariat was established in Venice, with Monica Eberle as the permanent secretary-general. The EAERE council in 2004/2005 was extended with the past president and the president-elect for the new term. Continuity of policy and activities was guaranteed. Since 2018, the monthly EAERE Highlights is the new EAERE Newsletter, and the quarterly EAERE Magazine, edited by Astrid Dannenberg, is a new outlet for all sorts of professional news. The website www.eaere.org now contains everything that is relevant to the EAERE.

\subsection{Annual Conferences}

The series of EAERE annual conferences continued. In the beginning, the number of participants was around 200. For a long time, this number fluctuated around 350, but since 2008 , the number of participants suddenly doubled. Once every 4 years a world congress was organized by the EAERE, the AERE, and later also the associations in other regions of the world. The First World Congress had 800 participants, but that number has now almost doubled as well. In the beginning, the organization was in the hands of the institution hosting the conference, but the strong growth in the number of participants required to involve professional conferences organizers and travel agents. Nevertheless, the EAERE annual conferences kept the special atmosphere of a combination of hard work and good company, which provided a home and a stimulus for further development of the field. Many people have contributed, as a member of the council, as a member of the local organizing committee, as a member of the scientific programme committee, or as one of the many people in the background who made it all possible.

\subsection{Awards}

Like every respectable association, the EAERE has also introduced a number of awards. The oldest award is the Erik Kempe Award, in cooperation with The Kempe Foundation in Umeå, Sweden. Since 1996, once every 2 years, the prize of 100,000 SEK is awarded for the best paper in the last 2 years, in the field of environmental and resource economics, and in a refereed journal with an author affiliated to a European institution. In 2005, the European Lifetime Achievement Award and the European Practitioner Achievement Award were introduced, with the first awardees David Pearce and Jos Delbeke. In 2019, the EAERE Fellows Programme replaced the European Lifetime Achievement Award. There are also awards for outstanding publication in ERE (since 2012), for ERC grants laureates and for researchers under the age of 40 (since 2018), and for the best doctoral dissertation (since 2019). 


\subsection{The Journal}

After almost 10 years, Kluwer Academic Publishers appointed Kerry Turner as the new editor of ERE, with Ian Bateman as assistant editor. The EAERE Council took the opportunity to suggest a few changes in the relationship with the journal: packaging the EAERE membership and the ERE subscription, having a say in the appointment of associate editors, and introducing an EAERE prize for best paper in ERE. In this time, a paper circulated comparing journals, published by commercial publishers, and nonprofit journals, usually published by university presses (Bergstrom 2001). In both cases, the academic community is doing most of the work, but commercial publishers set high prices and make large profits. Therefore, in 2013, the AERE decided to start a new Journal of the Association of Environmental and Resource Economists, published by the University of Chicago Press. However, the EAERE decided to hold on to ERE as the official journal, published by Kluwer Academic Publishers (that merged with Springer-Verlag in 2004). Especially when Ian Bateman became editor-in-chief of ERE, the relationship with the EAERE strengthened, the impact factor rose above 2, and the journal and the association flourished. Together with the AERE, the EAERE now has a second official journal: the Review of Environmental Economics and Policy, published by Oxford Academic, with the aim to bridge the gap between the academic journals and the general interest press (with an impact factor that rose above 6).

\subsection{The Field}

Environmental and resource economics is a well-established field now but it is not yet mainstream. Partly, this field has to mature further and partly, mainstream economics has to incorporate all the challenges caused by the success of our economies. We have entered the Anthropocene (Crutzen 2002) in which the economic activities of human beings have a significant impact on the natural environment. It is not easy to be an environmental economist. On the one hand, you have to keep track of the developments within economics, such as the rise of behavioural economics and the renewed attention for empirical research. On the other hand, you need to understand developments in natural sciences, such as climate change, and to be able to incorporate this in economic analyses. It is difficult but it is essential, and it is not an option to ignore this. As I wrote earlier, Paul Ehrlich had noted that environment was still not part of the top articles in economics. This may be due to a lack of interest from the top journals, but we the environmental economists also have to try to do better. It will change but it takes time. It is always interesting to see how the Committee for the Prize in Economics in honor of Alfred Nobel looks at this. In 2009, Elinor Ostrom received this "Nobel Prize". In response to the tragedy of the commons (Hardin 1968), she showed how local communities found ways to manage common natural resources (Ostrom 1990). In 2018, William Nordhaus received the Prize for developing the DICE (i.e., Dynamic Integrated Climate-Economy) model (Nordhaus 1992). It has been disappointing that other prominent environmental economists did not receive the Prize (yet), but it is a good start. After the revival about 30 years ago, the field has become broader and deeper. Within the scope of this article, it is not possible to describe all the developments. In order to get the picture, one can simply look at the programmes of the EAERE annual conferences. 


\subsection{The Future}

The EAERE has a bright future. Environmental and resource economics is there, and it is there to stay for some time, because it is essential for the future of our world. The EAERE is a very strong institution, with a professional secretariat, and with a very strong network of many people who are willing to contribute in one way or another. Only the new corona virus managed to stop the EAERE Annual Conference, in 2020! When I am writing this, I do not know how this will develop, but I am sure that when society gets this corona virus under control, the EAERE will quickly rise again. Environmental and resource economics has to bridge economics and natural sciences, but it also has to bridge academics and policy in this specific field. As I wrote earlier, from the start, policy has been an important topic for the EAERE annual conferences and for the journal ERE. The new official journal of the AERE and the EAERE even has the specific aim to bridge the gap between academics and the general interest. The relationship with the European Commission has always been important, and many environmental economists had an influence on policy in their respective countries. Since 2018, the EAERE has a Policy Outreach Committee, chaired by Jos Delbeke. It is interesting to see how consistent the EAERE is. He was also the person who arranged support from the European Commission for the First Annual Conference in Venice, 30 years ago.

\section{Conclusion}

The EAERE celebrates its 30th anniversary. This article distinguishes three stages. First, it sketches some debates in the pre-EAERE stage that led to the start of the EAERE. Second, it describes the initial years of the EAERE. Especially the younger generation may not know how the EAERE rose to existence, and it is good to give credit to the people who had the vision and the perseverance to make it happen. Third, it lists some of the important steps in the development of the EAERE to what it is now. The EAERE was an answer to the societal demand for integrating economics and the natural environment, and to the wish for more scientific cooperation in Europe.

The triangle annual conferences, journals and schools (accompanied by small-scale workshops, communication and policy outreach) facilitated the development of the field environmental and resource economics. At the annual conferences, the researchers meet and present their recent work. In the journals, they publish their papers after a careful review process. At the schools, they train the new generation, and build the networks of the future. The EAERE has been at the core of all of this. I congratulate the EAERE with its 30th anniversary and wish the EAERE many more years. I am grateful for the inspiration, and for the friendships that were built in being part of this journey.

\section{References}

Bergstrom TC (2001) Free labor for costly journals? Journal of Economic Perspectives 15(3):183-198 Crutzen PJ (2002) Geology of mankind: the anthropocene. Nature 415:23

Dasgupta PS, Heal GM (1979) Economic theory and exhaustible resources. Cambridge University Press, Cambridge

EAERE Newsletter (Spring 1991) Environ Resour Econ 1(1):119-123 
EAERE Newsletter (Fall 1991) Environ Resour Econ 1(4):415-418

EAERE Newsletter (Spring 1992) Environ Resour Econ 2(2):237-243

European Commission (1992) Human capital and mobility, annual report 1992. European Commission, Brussels: 306

Folmer H (2020) The rapid coming of age of EAERE. EAERE Mag 8:9-11

Hardin G (1968) The tragedy of the commons. Science 162(3859):1243-1248

Meadows DH, Meadows DL, Randers J, Behrens WW (1972) The limits to growth: a report for the club of Rome's project on the predicament of mankind. Universe Books, New York

Nordhaus WD (1992) The DICE model: background and structure of a dynamic integrated climate-economy model of the economics of global warming. Cowles Foundation discussion papers 1009. Yale University, New Haven

Opschoor JB, Jansen HMA (1991) The raison d'être of ERE. Environ Resour Econ 1(1):v-viii

Opschoor JB, Jansen HMA, Siniscalco D, Hoogervorst HAMP (1996) Environmental and resource economics' fifth anniversary. Environ Resour Econ 8(2):iii-vi

Ostrom E (1990) Governing the commons. Cambridge University Press, Cambridge

Pethig R (2020) There is magic in every beginning. EAERE Mag 8:12-14

Sabin P (2013) The bet: Paul Ehrlich, Julian Simon, and our gamble over earths future. Yale University Press, New Haven

Tinbergen J (1987) Kunnen wij de aarde beheren? Kok Agora, Kampen

Publisher's Note Springer Nature remains neutral with regard to jurisdictional claims in published maps and institutional affiliations. 